\title{
Komposisi dan luas relung makanan ikan belanak Chelon subviridis (Valenciennes, 1836) dan Moolgarda engeli (Bleeker, 1858) di Teluk Pabean, Kabupaten Indramayu, Provinsi Jawa Barat
}

[Diet composition and niche breadth of mullet Chelon subviridis (Valenciennes, 1836) and Moolgarda engeli (Bleeker, 1858) in Pabean Bay, Indramayu Subdistrict, West Java Province]

\author{
Gusti Abi Dzar Al Ghiffary ${ }^{1}$, M. Fadjar Rahardjo ${ }^{2,3}$, Ahmad Zahid ${ }^{4}$, Charles P.H. \\ Simanjuntak $^{2}$, Aries Asriansyah ${ }^{2}$, Reiza Maulana Aditriawan ${ }^{3}$ \\ ${ }^{1}$ Program Studi Manajemen Sumber Daya Perairan, MSP FPIK IPB \\ ${ }^{2}$ Departemen Manajemen Sumber Daya Perairan, FPIK IPB \\ Jln. Agatis, Kampus IPB Dramaga 16680 \\ ${ }^{3}$ Masyarakat Iktiologi Indonesia (MII) \\ ${ }^{4}$ Politeknik Kelautan dan Perikanan Jembrana
}

Diterima: 2 Oktober 2017; Disetujui: 20 Februari 2018

\begin{abstract}
Abstrak
Penelitian ini bertujuan untuk mengidentifikasi jenis dan komposisi serta luas dan tumpang tindih relung makanan ikan belanak di Teluk Pabean. Pengambilan contoh ikan dilakukan pada Juli hingga Desember 2016 dengan menggu-nakan alat tangkap sero dan jaring insang. Analisis data meliputi indeks bagian terbesar serta luas dan tumpang tindih relung makanan. Dua jenis ikan belanak, Chelon subviridis dan Moolgarda engeli, merupakan spesies yang banyak ditemukan di Teluk Pabean. Ukuran panjang tubuh C. subviridis yang diamati berkisar 73,34-185,72 mm dengan bobot 8,23$115,50 \mathrm{~g}$ dan panjang tubuh $M$. engeli berkisar 67,51-160,00 mm dengan bobot 6,91-96,70 g. Menu ma-kanan ikan belanak terdiri atas tiga kelompok besar, yaitu perifiton, larva organisme, dan detritus. Perifiton dari kelas Bacillariophyceae menjadi kelompok makanan yang banyak dimanfaatkan, khususnya Pleurosigma $(35,81)$ oleh $C$. subviridis dan Nitzschia $(27,89)$ oleh M. engeli. Perubahan komposisi jenis makanan terjadi pada setiap kelompok ukuran ikan. C. subviridis dan M. engeli memiliki relung makanan yang luas dengan nilai luas relung berturut-turut 5,995 dan 5,780. Luas relung makanan pada setiap kelompok ukuran ikan berbeda. Informasi mengenai luas relung makanan dapat menunjukkan adaptasi ikan belanak terhadap ketersediaan makanan di perairan.
\end{abstract}

Kata penting: belanak, komposisi makanan, luas relung, perifiton

\begin{abstract}
The aims of this research was to identify the diet and composition item as well as niche breadth and niche overlap of mullet in Pabean Bay. Fish sampling was carried out from July to December 2016 using trap nets and gill nets. Data analysis including preponderance index, niche breadth, and niche overlap. Chelon subviridis and Moolgarda engeli are two species of mullet that much found in Pabean Bay. The size of body length C. subviridis observed on ranged of 73,34-185,72 $\mathrm{mm}$ with a weight of 8,23-115,50 $\mathrm{g}$ and $M$. engeli ranged of 67,51-160,00 $\mathrm{mm}$ with a weight of 6,91$96,70 \mathrm{~g}$. Food menu of mullet consists of three groups, namely perifiton, larvae of marine organism, and detritus. Perifiton from Bacillariophyceae was a main diet, particularly Pleurosigma $(35,81)$ in C. subviridis and Nitzschia $(27,89)$ in $M$. engeli. Changed in composition of each item of diet occurred on any length size group during the observation. C. subviridis and M. engeli have a wide niche breadth with the value were 5,995 and 5,780. Niche breadth of each length group was different. Information on niche breadth indicated the adaptation of mullet to against the availability of diet in the water.
\end{abstract}

Key words: Diet composition, mullet, niche breadth, perifiton

\section{Pendahuluan}

Teluk Pabean terletak di wilayah pesisir Kabupaten Indramayu, Provinsi Jawa Barat. Teluk ini memiliki potensi perikanan laut yang cukup besar. Kondisi teluk yang dikelilingi oleh

\footnotetext{
$\triangle$ Penulis korespondensi

Alamat surel: gustighiffary@gmail.com
}

vegetasi mangrove di sekitarnya, secara tidak langsung memberikan asupan energi berupa makanan alami bagi ikan penghuni perairan tersebut. Tidak hanya makanan, secara ekologis area vegetasi mangrove juga berperan sebagai tempat pemijahan dan pembesaran ikan, udang, kepiting, kerang, dan spesies lainnya (Zamroni \& 
Rohyani 2008), yang satu diantaranya adalah ikan belanak.

Ikan belanak merupakan jenis ikan yang hidupnya bergerombol. Secara umum bentuk tubuhnya pipih sedikit memanjang. Ikan ini memiliki keunikan pada organ dan saluran pencernaannya, salah satunya terlihat pada bibir bagian atas lebih tebal daripada bagian bawah (Cardona 2016). Berbagai jenis belanak dideskripsikan sebagai pemakan detritus (Cardona 2016), karena makanannya berupa bahan organik yang dihasilkan oleh sedimen dasar perairan. Ikan belanak juga bisa memanfaatkan organisme dasar, makroalgae, plankton, dan bahan organik lainnya seperti atau bahan organik partikel halus (fine particulate organic matter) dan bahan organik partikel kasar (coarse particulate organic matter) (Isangedighi et al. 2009).

Sentosa \& Satria (2011) menyatakan bahwa ketersediaan makanan akan menentukan keberadaan populasi ikan di suatu perairan. Ketersediaan makanan dan ikan belanak yang berlimpah di Teluk Pabean dapat dijadikan dasar kajian terkait relung ekologi di perairan tersebut. Pengelolaan sumber daya perairan yang optimal juga memerlukan pemahaman terkait potensi dan karakteristik perairan tersebut, yaitu ketersediaan makanan alami serta sumber daya ikan yang dapat memanfaatkan makanan tersebut (Rachman et al. 2012).

Kajian mengenai makanan ikan belanak di Teluk Pabean belum pernah dilakukan. Kajian ini sudah pernah dilakukan di beberapa tempat, yaitu di danau pesisir Ghana (Blay 1995), estuari Delta Nigeria (Isangedighi et al. 2009), dan estuari Merbok, Kedah, Malaysia (Fatema et al. 2015a; 2015b). Kajian mengenai makanan ikan belanak di Teluk Pabean perlu dilakukan karena makanan merupakan faktor yang menentukan kelangsungan hidup ikan seperti pertumbuhan dan reproduksi. Informasi mengenai makanan sangat dibutuhkan terutama di Teluk Pabean yang memiliki sumber daya ikan dan makanan yang melimpah. Sementara itu, kajian mengenai interaksi makanan ikan belanak pada kedua spesies berbeda sudah pernah dilakukan yaitu pada Valamugil buchanani dengan Liza vaigiensis di estuari Srilanka (Wijeyaratne \& Costa 1990).

Penelitian ini bertujuan untuk mengidentifikasi jenis dan komposisi makanan serta menganalisis luas dan tumpang tindih relung makanan ikan belanak di Teluk Pabean. Penelitian ini diharapkan dapat memberikan informasi berupa pemahaman dasar untuk mengelola perikanan di Teluk Pabean, sehingga dapat terbentuk sistem pengelolaan sumber daya perikanan yang lestari di Teluk Pabean, Jawa Barat.

\section{Bahan dan metode}

Penelitian dilaksanakan di Teluk Pabean, Kabupaten Indramayu, Provinsi Jawa Barat dengan waktu pengambilan contoh ikan berlangsung pada Juli hingga Desember 2016. Lokasi pengambilan contoh ikan dibagi menjadi tiga zona (Gambar 1) berdasarkan perbedaan karakteristik perairannya. Zona 1 adalah zona yang berdekatan dengan tempat pemasangan alat tangkap sero, tambak ikan, dan tiram serta vegetasi mangrove. Zona 2 adalah zona yang berdekatan dengan muara Sungai Cimanuk dan vegetasi mangrove. Zona 3 adalah zona yang berhadapan dengan laut lepas. 


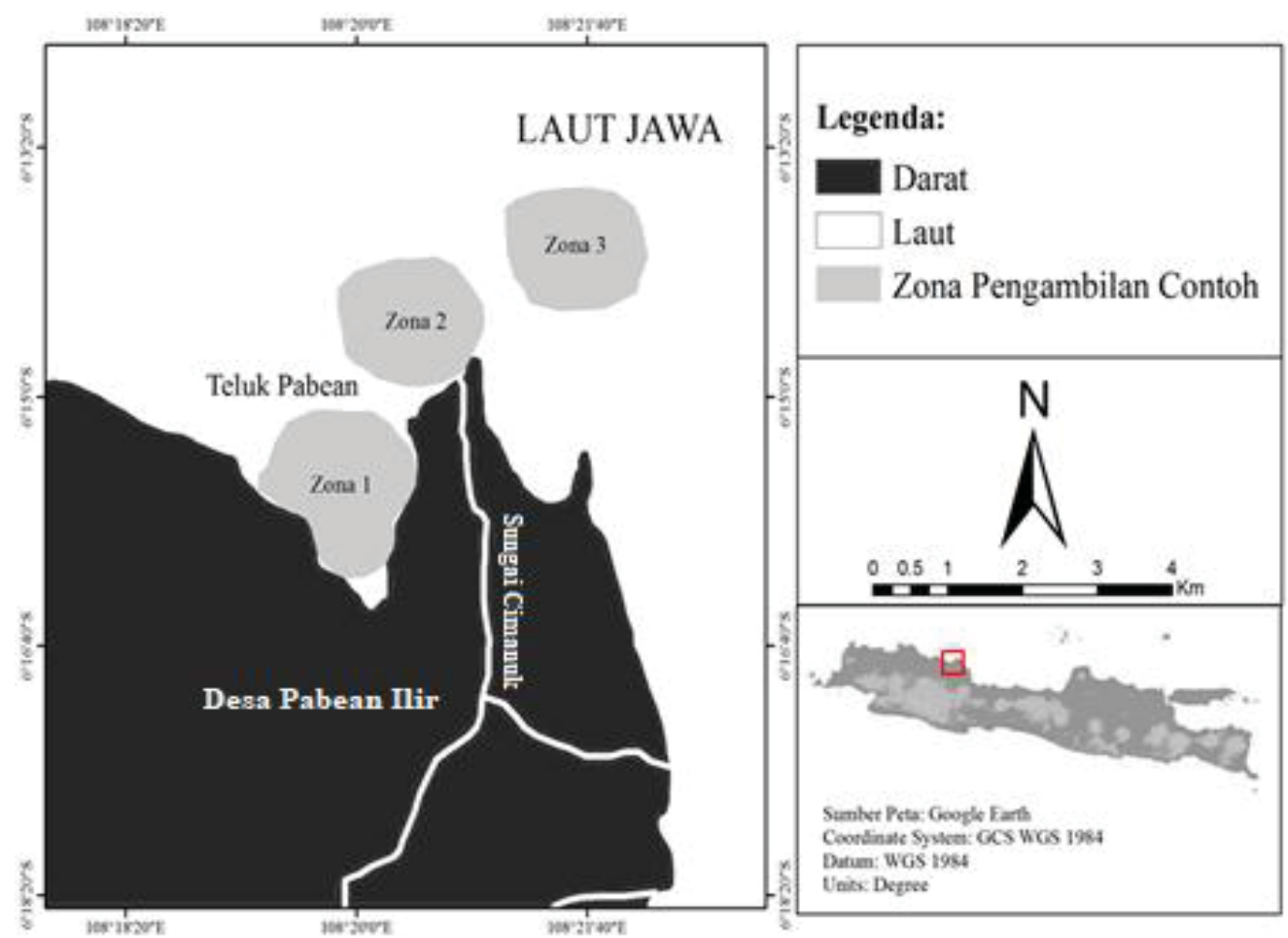

Gambar 1 Lokasi pengambilan contoh ikan di Teluk Pabean

Pengambilan contoh ikan menggunakan alat tangkap sero dengan tinggi $1 \mathrm{~m}$, lebar $3 \mathrm{~m}$, panjang penaju $100 \mathrm{~m}$, dan mata jaring 0,04 inci serta jaring insang dengan panjang $100 \mathrm{~m}$, tinggi $1 \mathrm{~m}$, dan mata jaring 1,5-1,75 inci. Alat tangkap sero dan jaring insang digunakan pada Zona 1 dan 2, sedangkan pada Zona 3 hanya jaring insang.

Sero digunakan pada Zona 1 dan 2 karena kondisi perairan yang relatif dangkal serta prinsip kerja sero yang dipengaruhi oleh pasang surut. Sero dioperasikan sejak sore hari dan diangkat pagi hari.

Jaring insang digunakan pada Zona 1, 2, dan 3 karena alat tangkap ini merupakan alat tangkap sederhana yang banyak digunakan untuk menangkap ikan. Jaring ini termasuk tipe jaring yang relatif transparan di dalam air, sehingga sulit terlihat oleh ikan. Jaring insang dioperasikan selama 1 jam, kemudian diangkat.
Ikan yang tertangkap dimasukkan ke dalam kantung plastik, kemudian kantung tersebut diberi tanda dengan label sesuai dengan zona pengambilan contoh dan ditambahkan formalin $10 \%$ sebagai bahan pengawet. Ikan dibawa ke laboratorium untuk dianalisis.

Analisis contoh ikan dilakukan di Laboratorium Biologi Makro, Divisi Ekobiologi dan Konservasi Sumber Daya Perairan, Departemen Manajemen Sumberdaya Perairan, Fakultas Perikanan dan Ilmu Kelautan, Institut Pertanian Bogor. Panjang baku diukur dengan penggaris, lebar bukaan mulut dan tinggi kepala diukur dengan jangka sorong, serta bobot total ditimbang dengan timbangan digital. Selanjutnya contoh ikan dibedah menggunakan alat bedah tanpa merusak saluran pencernaannya.

Organ pencernaan (tembolok dan usus) dikeluarkan dari rongga tubuh. Masing-masing organ tersebut dipisahkan. Gonad ikan diamati 
untuk menentukan jenis kelaminnya. Tembolok dan usus ikan diamati untuk menganalisis perbedaan jenis makanan yang terdapat di dalamnya. Jumlah pilorik kaeka dihitung, dan usus diukur panjangnya dengan menggunakan penggaris. Tembolok dan usus ikan diawetkan dalam larutan formalin $4 \%$.

Pengamatan isi saluran pencernaan dilakukan dengan cara membedah tembolok serta usus ikan yang sudah diawetkan dan semua isinya dikeluarkan. Seluruh isi saluran pencernaan diamati menggunakan mikroskop monokuler dengan pembesaran $10 \times 10$ kali. Organisme jenis makanan yang terdapat dalam tembolok dan usus diidentifikasi hingga takson terendah yang memungkinkan dengan menggunakan buku identifikasi Davis (1955) dan Yamaji (1979).

Analisis data untuk menentukan jenis dan komposisi makanan menggunakan indeks bagian terbesar (Natarajan \& Jhingran 1961), yaitu :

$$
\mathrm{I}_{\mathrm{i}}=\frac{\mathrm{V}_{\mathrm{i}} \times \mathrm{O}_{\mathrm{i}}}{\sum_{\mathrm{i}}^{\mathrm{n}}\left(\mathrm{V}_{\mathrm{i}} \mathrm{xO}_{\mathrm{i}}\right)} \times 100
$$

Keterangan: $\mathrm{I}_{\mathrm{i}}=$ indeks bagian terbesar, $\mathrm{V}_{\mathrm{i}}=$ persentase volume makanan jenis ke-I, $\mathrm{O}_{\mathrm{i}}=$ persentase frekuensi kejadian makanan jenis ke-I, $\mathrm{n}=$ jumlah total organisme makanan $(i=1,2,3, \ldots . . \mathrm{n})$

Luas relung makanan menggambarkan sejumlah sumber daya makanan yang dimanfaatkan oleh suatu organisme. Analisis luas relung makanan menggunakan rumus indeks Levins (Krebs 1989), yaitu :

$$
\mathrm{B}=\frac{1}{\sum \mathrm{P}_{\mathrm{j}}^{2}}
$$

Keterangan: $\mathrm{B}=$ luas relung makanan Levins, $\mathrm{P}_{\mathrm{j}}=$ proporsi makanan ke-j yang ditemukan atau dimanfaatkan oleh ikan

$$
\left.\mathrm{P}_{\mathrm{j}}=\mathrm{N}_{\mathrm{j}} / \mathrm{Y}\right)\left(\sum \mathrm{P}_{\mathrm{j}}=1,0\right)
$$

Keterangan: $\mathrm{N}_{\mathrm{j}}=$ jumlah individu pada makanan ke-j, $\mathrm{Y}=$ jumlah total makanan $\left(\Sigma \mathrm{N}_{\mathrm{j}}\right)$

Pembakuan nilai luas relung makanan bernilai 0-1 dengan menggunakan rumus perhitungan Hulbert (1978) in Krebs (1989) :

$$
\mathrm{B}_{\mathrm{A}}=\frac{\mathrm{B}-1}{\mathrm{n}-1}
$$

Keterangan: $\mathrm{B}_{\mathrm{A}}=$ pembakuan luas relung makanan Levins $(0-1), B=$ luas relung makanan Levins, $n=$ jumlah organisme makanan yang dimanfaatkan

Tumpang tindih relung makanan dapat menunjukkan interaksi antarspesies ikan dengan melihat kesamaan dalam memanfaatkan sumber daya makanan. Analisis tumpang tindih relung makanan menggunakan index Morisita yang telah disederhanakan oleh Horn (Krebs 1989) yaitu :

$$
\mathrm{C}_{\mathrm{H}}=\frac{2 \sum_{\mathrm{i}}^{\mathrm{n}}\left(\mathrm{P}_{\mathrm{ij}} \times \mathrm{P}_{\mathrm{ik}}\right)}{\sum_{\mathrm{i}}^{\mathrm{n}} \mathrm{P}_{\mathrm{ij}}^{2}+\sum_{\mathrm{i}}^{\mathrm{n}} \mathrm{P}_{\mathrm{ik}}^{2}}
$$

Keterangan: $\mathrm{C}_{\mathrm{H}}=$ tumpang tindih relung makanan, $\mathrm{P}_{\mathrm{ij}}$ dan $\mathrm{P}_{\mathrm{ik}}=$ proporsi jenis organisme makanan ke-i yang dimanfaatkan dua kelompok ikan ke-j dan ke-k, n= jumlah total organisme makanan $(i=1,2,3, \ldots . . n)$

\section{Hasil}

Sebaran ukuran ikan

Ikan contoh yang tertangkap berjumlah 161 ekor yang terdiri atas 127 ekor C. subviridis dan 34 ekor $M$. engeli. Kisaran panjang baku ikan C. subviridis yang tertangkap adalah 73,34185,72 mm dengan bobot 8,23-115,50 g dan $M$. engeli adalah 67,51-160,00 $\mathrm{mm}$ dengan bobot 6,91-96,70 g. Kisaran panjang tersebut terbagi menjadi tiga kelompok ukuran panjang baku, yaitu kecil (<100 mm), sedang (100-150 mm), dan besar $(>150 \mathrm{~mm})$. Ikan belanak yang tertangkap umumnya terdapat pada kelompok ukuran panjang ikan sedang. Kelompok ukuran ikan contoh disajikan pada Tabel 1.

\section{Komposisi makanan ikan belanak}

Makanan yang ditemukan pada C. subviridis dan $M$. engeli terdiri atas tiga kelompok, yaitu perifiton, larva organisme, dan detritus. Kelompok perifiton Bacillariophyceae, Cyano- 
phyceae, dan Dinophyceae, serta larva Nematoda, larva Crustacea, larva Ciliata, larva Gastropoda, larva Tentaculata, dan larva Polychaeta ditemukan pada C. subviridis. Bacillariophyceae, Cyanophyceae, dan detritus adalah tiga jenis makanan yang memiliki indeks bagian terbesar (IBT) tertinggi pada C. subviridis (Gambar 2a). Pleurosigma merupakan perifiton yang memiliki nilai IBT tertinggi pada C. subviridis (Tabel 2).
Pada $M$. engeli hanya ditemukan kelompok perifiton Bacillariophyceae dan Cyanophyceae, serta larva Nematoda, larva Crustacea, dan larva Ciliata. Tiga jenis makanan yang memiliki IBT tertinggi pada $M$. engeli yaitu Bacillariophyceae, larva Nematoda, dan detritus (Gambar 2b). Nitzschia merupakan perifiton yang memiliki nilai IBT tertinggi pada M. engeli (Tabel 2).

Tabel 1 Kelompok ukuran panjang ikan belanak di perairan Teluk Pabean pada bulan Juli-Desember 2016

\begin{tabular}{lcc}
\hline \multicolumn{1}{c}{ Jenis ikan } & Kelompok ukuran panjang ikan & Frekuensi (ekor) \\
\hline C. subviridis & Kecil & 8 \\
& Sedang & 102 \\
M. engeli & Besar & 17 \\
& Kecil & 6 \\
& Sedang & 26 \\
\hline
\end{tabular}
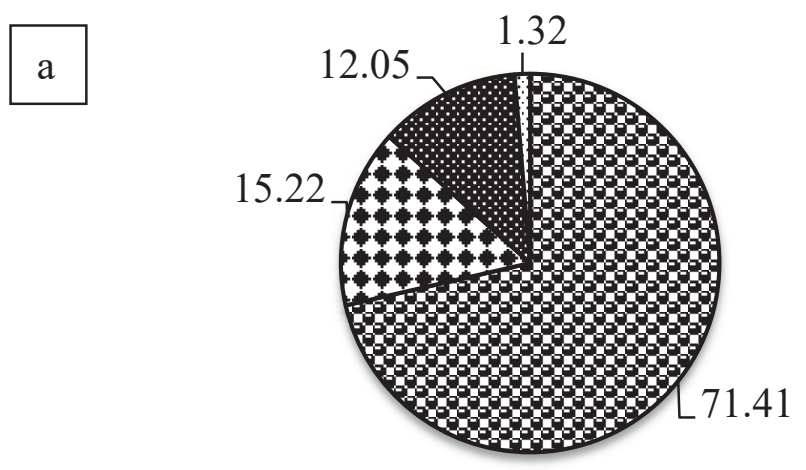

\author{
B Bacillariophyceae \\ $\boldsymbol{\omega}$ Cyanophyceae \\ Detritus \\ ․․․․ lainnya
}

\title{
3.57
}

$\mathrm{b}$

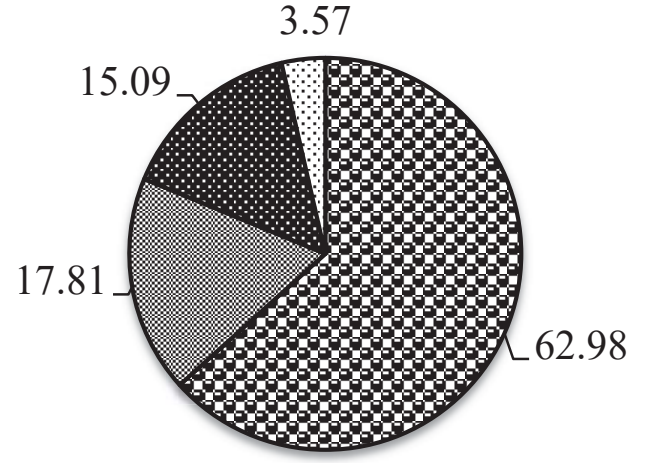

\author{
๑ Bacillariophyceae \\ ㄴ. Larva Nematoda \\ Detritus \\ Q Jenis lainnya
}

Gambar 2 Kelompok makanan C. subviridis (a) dan M. engeli (b) di Teluk Pabean berdasarkan indeks bagian terbesar 
Tabel 2 Indeks bagian terbesar jenis makanan ikan belanak di Teluk Pabean

\begin{tabular}{|c|c|c|}
\hline Jenis organisme makanan & C. subviridis & M. engeli \\
\hline \multicolumn{3}{|l|}{ Bacillariophyceae } \\
\hline Amphora & 0,785 & 0,856 \\
\hline Asterolampra & 0,015 & \\
\hline Chaetoceros & 0,026 & \\
\hline Cocconeis & 0,080 & 0,031 \\
\hline Coscinodiscus & 12,045 & 10,621 \\
\hline Gammatophora & 1,194 & 0,382 \\
\hline Diatoma & 0,025 & \\
\hline Gyrosigma & 0,428 & 0,116 \\
\hline Hemiaulus & 0,025 & \\
\hline Licmophora & 2,537 & 2,273 \\
\hline Navicula & 0,308 & 0,338 \\
\hline Nitzschia & 18,054 & 27,895 \\
\hline Pleurosigma & 35,809 & 20,407 \\
\hline Rhabdonema & 0,037 & 0,051 \\
\hline Rhizosolenia & 0,018 & \\
\hline Thalassiothrix & 0,008 & \\
\hline Triceratium & 0,012 & 0,007 \\
\hline \multicolumn{3}{|l|}{ Larva Ciliata } \\
\hline Helicostomella & 0,103 & 0,046 \\
\hline Parafavella & 0,015 & 0,080 \\
\hline \multicolumn{3}{|l|}{ Larva Crustacea } \\
\hline Calanus & 0,127 & 0,074 \\
\hline Nauplius & 0,209 & 0,158 \\
\hline Oithona & 0,060 & 0,012 \\
\hline \multicolumn{3}{|l|}{ Cyanophyceae } \\
\hline Merismopedia & 15,220 & 3,169 \\
\hline \multicolumn{3}{|l|}{ Dinophyceae } \\
\hline Dinophysis & 0,039 & \\
\hline Peridinium & 0,069 & \\
\hline Pyrocystis & 0,010 & \\
\hline \multicolumn{3}{|l|}{ Larva Polychaeta } \\
\hline Travisiopsis & 0,006 & \\
\hline \multicolumn{3}{|l|}{ Larva Tentaculata } \\
\hline Notholca & 0,034 & \\
\hline Larva Gastropoda & 0,043 & \\
\hline Larva Nematoda & 0,607 & 17,652 \\
\hline Detritus & 12,050 & 15,833 \\
\hline
\end{tabular}

Makanan ikan belanak setiap bulan cenderung memiliki kesamaan, hanya saja proporsi dan komposisi makanannya yang berbeda. Komposisi makanan yang ditemukan pada C. subviridis berjumlah 31 (Tabel 3). Coscinodiscus, Nitzschia, dan Pleurosigma, merupakan jenis perifiton yang ditemukan pada setiap bulan. Pleurosigma juga merupakan jenis perifiton yang memiliki proporsi relatif tinggi dibanding-kan dengan jenis perifiton lainnya. Tidak hanya perifiton, detritus juga memiliki proporsi yang relatif tinggi pada setiap bulan pengamatan. Thalassiothrix dan Asterolampra merupakan jenis perifiton yang memiliki proporsi terendah dan hanya ditemukan pada bulan Agustus dan Desember. 
Tabel 3 Indeks bagian terbesar jenis makanan C. subviridis di Teluk Pabean bulan Juli-Desember 2016

\begin{tabular}{|c|c|c|c|c|c|c|}
\hline \multirow{2}{*}{ Jenis organisme makanan } & \multicolumn{6}{|c|}{ Indeks Bagian Terbesar } \\
\hline & Juli & Agustus & September & Oktober & November & Desember \\
\hline \multicolumn{7}{|l|}{ Bacillariophyceae } \\
\hline Amphora & 1,252 & 0,035 & & & 0,151 & 0,154 \\
\hline Asterolampra & & & & & & 0,012 \\
\hline Chaetoceros & 0,044 & & & & & \\
\hline Cocconeis & 0,163 & & & 0,121 & & \\
\hline Coscinodiscus & 12,641 & 5,646 & 8,867 & 3,497 & 13,067 & 10,843 \\
\hline Gammatophora & & & & & & 27,851 \\
\hline Diatoma & 0,124 & & & & & \\
\hline Gyrosigma & 0,040 & & & & & 3,253 \\
\hline Hemiaulus & & & & & & 0,080 \\
\hline Licmophora & & & 10,786 & 4,420 & & \\
\hline Navicula & 0,057 & 0,007 & & & & 1,458 \\
\hline Nitzschia & 25,119 & 9,851 & 19,227 & 35,007 & 46,313 & 14,289 \\
\hline Pleurosigma & 56,602 & 38,588 & 50,872 & 50,118 & 35,047 & 11,104 \\
\hline Rhabdonema & & & & & & 0,089 \\
\hline Rhizosolenia & & & & & & 0,029 \\
\hline Thalassiothrix & & 0,012 & & & & \\
\hline Triceratium & & & & & & 0,067 \\
\hline \multicolumn{7}{|l|}{ Larva Ciliata } \\
\hline Helicostomella & 0,007 & 0,004 & 0,530 & 0,221 & & \\
\hline Parafavella & & & & & & 0,099 \\
\hline \multicolumn{7}{|l|}{ Larva Crustacea } \\
\hline Calanus & & & 0,105 & 0,029 & 0,016 & 0,091 \\
\hline Nauplius & 0,018 & & 0,015 & 0,044 & 0,016 & 0,383 \\
\hline Oithona & & & 0,032 & & 0,094 & 0,065 \\
\hline \multicolumn{7}{|l|}{ Cyanophyceae } \\
\hline Merismopedia & 0,355 & 40,159 & & & 0,030 & \\
\hline \multicolumn{7}{|l|}{ Dinophyceae } \\
\hline Dinophysis & & & & & 0,077 & 0,005 \\
\hline Peridinium & & & & & & 0,055 \\
\hline Pyrocystis & & & 0,114 & & & \\
\hline \multicolumn{7}{|l|}{ Larva Polychaeta } \\
\hline Travisiopsis & & & & & 0,038 & \\
\hline \multicolumn{7}{|l|}{ Larva Tentaculata } \\
\hline Notholca & & & & & & 0,055 \\
\hline Larva Gastropoda & & & & & & 0,138 \\
\hline Larva Nematoda & & & & & & 6,345 \\
\hline Detritus & 3,577 & 5,699 & 9,452 & 6,543 & 5,152 & 23,536 \\
\hline
\end{tabular}

M. engeli memiliki komposisi makanan yang lebih sedikit dibandingkan C. subviridis. Makanan yang ditemukan pada $M$. engeli berjumlah 19 (Tabel 4). Nitzschia, dan detritus merupakan makanan yang ditemukan pada setiap bulan. Berbeda dari C. subviridis, jenis perifiton yang memiliki proporsi relatif tinggi pada setiap bulan hanya Nitzschia. Proporsi makanan terendah dimiliki Triceratium dan hanya ditemukan pada bulan Desember. 
Tabel 4 Indeks bagian terbesar jenis makanan M. engeli di Teluk Pabean pada bulan Juli-Desember 2016

\begin{tabular}{|c|c|c|c|c|c|c|}
\hline \multirow{2}{*}{ Jenis organisme makanan } & \multicolumn{6}{|c|}{ Indeks Bagian Terbesar } \\
\hline & Juli & Agustus & September & Oktober & November & Desember \\
\hline \multicolumn{7}{|l|}{ Bacillariophyceae } \\
\hline Amphora & 4,334 & 3,471 & & & 1,769 & 0,073 \\
\hline Cocconeis & & & & & 0,221 & \\
\hline Coscinodiscus & 65,880 & 8,331 & & 3,548 & 27,892 & 1,574 \\
\hline Gammatophora & & & & & & 2,730 \\
\hline Gyrosigma & & & & & & 0,355 \\
\hline Licmophora & & & & 31,386 & & \\
\hline Navicula & & & & & & 2,413 \\
\hline Nitzschia & 26,887 & 8,516 & 12,564 & 41,894 & 14,747 & 25,009 \\
\hline Pleurosigma & & 33,082 & 11,640 & 14,830 & 50,691 & 3,656 \\
\hline Rhabdonema & & & & & & 0,052 \\
\hline Triceratium & & & & & & 0,007 \\
\hline \multicolumn{7}{|l|}{ Larva Ciliata } \\
\hline Helicostomella & & & 0,740 & & 0,081 & \\
\hline Parafavella & & & & & & 0,656 \\
\hline \multicolumn{7}{|l|}{ Larva Crustacea } \\
\hline Calanus & & & & & & 0,451 \\
\hline Nauplius & & & & & 0,080 & 0,554 \\
\hline Oithona & & & & & & 0,038 \\
\hline \multicolumn{7}{|l|}{ Cyanophyceae } \\
\hline Merismopedia & & 33,324 & 58,482 & & & \\
\hline Larva Nematoda & & & 6,873 & & & 35,620 \\
\hline Detritus & 2,899 & 13,276 & 9,700 & 8,342 & 4,520 & 13,952 \\
\hline
\end{tabular}

Perifiton dan detritus tidak hanya dominan pada setiap bulan pengamatan, tetapi juga pada setiap kelompok ukuran ikan. Jenis perifiton yang dominan pada setiap kelompok ukuran ikan C. subviridis memiliki perbedaan (Tabel 5). Amphora, Coscinodiscus, Gyrosigma, Navicula, Nitzschia, Pleurosigma, dan Merismopedia merupakan perifiton yang ditemukan pada setiap kelompok ukuran. Tidak hanya perifiton, detritus juga ditemukan pada setiap kelompok ukuran.

C. subviridis pada kelompok ukuran sedang memiliki variasi makanan yang tinggi dibandingkan kelompok ukuran lainnya. Pleurosigma merupakan perifiton yang memiliki proporsi relatif tinggi pada setiap kelompok ukur- annya, sedangkan Thalassiothrix, Pyrocystis, dan Travisiopsis memiliki proporsi terendah dan hanya ditemukan pada kelompok ukuran ikan sedang.

Amphora, Coscinodiscus, Nitzschia, dan Pleurosigma merupakan perifiton yang ditemukan pada setiap kelompok ukuran ikan $M$. engeli (Tabel 6). Detritus juga ditemukan pada setiap kelompok ukuran ikan. Pada kelompok ukuran ikan sedang ditemukan variasi makanan yang tinggi. Nitzschia memiliki proporsi yang relatif tinggi pada setiap kelompok ukuran, sedangkan Triceratium memiliki proporsi terendah dan hanya ditemukan pada kelompok ukuran ikan sedang. 
Tabel 5 Indeks bagian terbesar jenis makanan C. subviridis di Teluk Pabean berdasarkan kelompok ukuran panjang baku

\begin{tabular}{|c|c|c|c|}
\hline \multirow{2}{*}{ Jenis organisme makanan } & \multicolumn{3}{|c|}{ C. subviridis } \\
\hline & Kecil & sedang & besar \\
\hline \multicolumn{4}{|l|}{ Bacillariophyceae } \\
\hline Amphora & 3,272 & 0,123 & 0,274 \\
\hline Asterolampra & & 0,002 & \\
\hline Chaetoceros & 0,447 & & \\
\hline Cocconeis & 0,679 & 0,005 & \\
\hline Coscinodiscus & 18,847 & 11,997 & 2,584 \\
\hline Gammatophora & & 4,254 & 0,120 \\
\hline Diatoma & 1,256 & & \\
\hline Gyrosigma & 0,068 & 0,550 & 0,018 \\
\hline Hemiaulus & & 0,013 & \\
\hline Licmophora & & 0,339 & \\
\hline Navicula & 0,417 & 0,222 & 0,045 \\
\hline Nitzschia & 27,754 & 25,274 & 14,064 \\
\hline Pleurosigma & 33,846 & 44,319 & 33,271 \\
\hline Rhabdonema & 0,208 & 0,007 & \\
\hline Rhizosolenia & 0,152 & 0,001 & \\
\hline Thalassiothrix & & 0,001 & \\
\hline Triceratium & 0,029 & 0,008 & \\
\hline \multicolumn{4}{|l|}{ Larva Ciliata } \\
\hline Helicostomella & & 0,014 & 0,075 \\
\hline Parafavella & 0,033 & 0,006 & 0,035 \\
\hline \multicolumn{4}{|l|}{ Larva Crustacea } \\
\hline Calanus & & 0,015 & 0,226 \\
\hline Nauplius & & 0,091 & 0,056 \\
\hline Oithona & & 0,024 & 0,018 \\
\hline \multicolumn{4}{|l|}{ Cyanophyceae } \\
\hline Merismopedia & 3,607 & 1,301 & 33,361 \\
\hline \multicolumn{4}{|l|}{ Dinophyceae } \\
\hline Dinophysis & & 0,005 & 0,928 \\
\hline Peridinium & & 0,009 & \\
\hline Pyrocystis & & 0,001 & \\
\hline \multicolumn{4}{|l|}{ Larva Polychaeta } \\
\hline Travisiopsis & & 0,001 & \\
\hline \multicolumn{4}{|l|}{ Larva Tentaculata } \\
\hline Notholca & & 0,009 & \\
\hline Larva Gastropoda & & 0,023 & \\
\hline Larva Nematoda & & 0,668 & \\
\hline Detritus & 9,386 & 10,717 & 14,925 \\
\hline
\end{tabular}


Tabel 6 Indeks bagian terbesar jenis makanan M. engeli di Teluk Pabean berdasarkan kelompok ukuran panjang baku

\begin{tabular}{|c|c|c|c|}
\hline \multirow{2}{*}{ Jenis organisme makanan } & \multicolumn{3}{|c|}{ M. engeli } \\
\hline & Kecil & sedang & besar \\
\hline \multicolumn{4}{|l|}{ Bacillariophyceae } \\
\hline Amphora & 0,322 & 0,483 & 1,260 \\
\hline Cocconeis & & 0,013 & \\
\hline Coscinodiscus & 1,158 & 12,405 & 3,025 \\
\hline Gammatophora & 0,983 & & 1,927 \\
\hline Gyrosigma & & 0,874 & 1,171 \\
\hline Licmophora & 40,963 & 0,083 & \\
\hline Navicula & 0,369 & 0,660 & \\
\hline Nitzschia & 35,634 & 24,179 & 62,270 \\
\hline Pleurosigma & 6,452 & 16,062 & 30,347 \\
\hline Rhabdonema & & 0,021 & \\
\hline Triceratium & & 0,003 & \\
\hline \multicolumn{4}{|l|}{ Larva Ciliata } \\
\hline Helicostomella & & 0,019 & \\
\hline Parafavella & & 0,267 & \\
\hline \multicolumn{4}{|l|}{ Larva Crustacea } \\
\hline Calanus & & 0,184 & \\
\hline Nauplius & 0,051 & 0,245 & \\
\hline Oithona & 0,038 & 0,007 & \\
\hline \multicolumn{4}{|l|}{ Cyanophyceae } \\
\hline Merismopedia & & 1,978 & \\
\hline Larva Nematoda & & 29,386 & \\
\hline Detritus & 14,032 & 13,131 & 31,677 \\
\hline
\end{tabular}

Komposisi perifiton kelas Bacillariophyceae yang tinggi ditemukan pada kelompok ukuran sedang pada kedua spesies ikan. Makanan yang juga dominan ditemukan pada kelompok ukuran tersebut adalah larva organisme, seperti larva Ciliata, larva Crustacea, dan larva $\mathrm{Ne}$ matoda pada kedua spesies. Larva Polychaeta, larva Tentaculata, dan larva Gastropoda hanya ditemukan pada kelompok ukuran sedang C. subviridis.

\section{Luas dan tumpang tindih relung makanan}

Variasi makanan yang dimanfaatkan ikan belanak berhubungan dengan relung makanannya. Luas relung makanan C. subviridis yaitu
5,995 dengan pembakuan luas relung makanan 0,167. Nilai luas relung makanan relatif berbeda pada setiap kelompok ukuran. Kelompok ukuran ikan sedang memiliki nilai luas relung yang tinggi dibandingkan kelompok ukuran lain (Tabel 7).

Luas relung makanan $M$. engeli yaitu 5,780 dengan pembakuan luas relung makanan 0,159 . Nilai luas relung yang berbeda pada setiap kelompok ukuran panjang juga terjadi pada $M$. engeli. Kelompok ukuran ikan sedang $M$. engeli memiliki nilai luas relung yang tinggi dibandingkan kelompok ukuran lainnya (Tabel 8). Selain luas relung makanan, C. subviridis dan M. engeli juga memiliki tumpang tindih relung makanan yang relatif rendah yaitu 0,037 . 
Tabel 7 Luas relung makanan C. subviridis di Teluk Pabean pada bulan Juli-Desember 2016

\begin{tabular}{lccc}
\hline & Luas relung makanan & \multicolumn{3}{c}{ Kelompok ukuran panjang } \\
\cline { 2 - 4 } & Kecil & sedang & besar \\
\hline $\mathrm{B}$ & 5,279 & 6,384 & 2,347 \\
$\mathrm{~B}_{\mathrm{A}}$ & 0,153 & 0,192 & 0,048 \\
$\mathrm{~B}$ & & 5,995 & \\
$\mathrm{~B}_{\mathrm{A}}$ & & 0,167 & \\
\hline
\end{tabular}

* B: luas relung makanan; $\mathrm{B}_{\mathrm{A}}$ : pembakuan luas relung makanan $(0-1)$

Tabel 8 Luas relung makanan M. engeli di Teluk Pabean pada bulan Juli-Desember 2016

\begin{tabular}{lccc}
\hline & Luas relung makanan & \multicolumn{3}{c}{ Kelompok ukuran panjang } \\
\cline { 2 - 4 } & Kecil & sedang & besar \\
\hline $\mathrm{B}$ & 2,706 & 4,678 & 3,371 \\
$\mathrm{~B}_{\mathrm{A}}$ & 0,061 & 0,131 & 0,085 \\
$\mathrm{~B}$ & & 5,780 & \\
$\mathrm{~B}_{\mathrm{A}}$ & & 0,159 & \\
\hline
\end{tabular}

* B: luas relung makanan; $\mathrm{B}_{\mathrm{A}}$ : pembakuan luas relung makanan (0-1)

\section{Pembahasan}

\section{Kelompok ukuran ikan}

Dua spesies ikan hasil tangkapan memiliki ukuran dan jumlah yang berbeda (Tabel 1). Ikan yang dominan tertangkap terdapat pada kelompok ukuran sedang dengan jumlah tangkapan 102 ekor C. subviridis dan 26 ekor M. engeli. Tangkapan pada kelompok ukuran lainnya relatif sedikit, terutama pada kelompok ukuran kecil $C$. subviridis, hanya diperoleh 8 ekor dan kelompok ukuran besar M. engeli hanya diperoleh 2 ekor. Ikan berukuran sedang (100-150 mm) yang dominan tertangkap diduga karena adanya faktor selektivitas alat tangkap. Alat tangkap yang digunakan hanya memiliki satu ukuran mata jaring atau selektivitasnya tinggi, yaitu sero $(0,04$ inci) dan jaring insang (1,5-1,75 inci). Hal tersebut diduga akan menghasilkan tangkapan ikan dengan ukuran yang seragam.

Ukuran ikan yang tertangkap pada kedua spesies didominasi oleh ikan berukuran sedang (100-150 mm). Hal tersebut berbeda dari peneli- tian Djumanto et al. (2015), C. subviridis yang banyak tertangkap di Sungai Opak umumnya berukuran 100-199 mm. Perbedaan ukuran panjang ikan belanak yang tertangkap juga terjadi di perairan Ujung Pangkah, ikan belanak yang tertangkap berukuran kecil dengan kisaran panjang 125-165 mm (Sulistiono et al. 2001). Djumanto et al. (2015) menyatakan bahwa perbedaan ukuran panjang yang tertangkap dapat mengindikasikan adanya perbedaan umur serta musim pemijahan ikan tersebut dan akan berkaitan dengan kondisi habitatnya.

Jumlah ikan C. subviridis yang tertangkap lebih banyak daripada $M$. engeli. Hal tersebut diduga karena kebiasaan C. subviridis yang hidup bergerombol (Harrison \& Senou 1999) dan didukung oleh kondisi Teluk Pabean yang merupakan perairan estuari cocok untuk habitat ikan tersebut (Djumanto et al. 2015). Berbeda dengan $M$. engeli yang lebih banyak hidup di sekitar pantai berpasir atau berlumpur serta daerah gosong pasir yang dangkal (Harrison \& Senou 1999). 
Makanan ikan belanak

Pengelompokan makanan berdasarkan indeks bagian terbesar menunjukkan bahwa makanan ikan C. subviridis dan M. engeli didominasi oleh perifiton, larva organisme, dan detritus (Gambar 2). C. subviridis memanfaatkan perifiton kelas Bacillariophyceae sebagai kelompok makanan utama. Proporsi Bacillariophyceae yang dominan dibandingkan Cyanophyceae dan detritus mengindikasikan bahwa keberadaan perifiton kelas Bacillariophyceae melimpah di perairan estuari hingga laut lepas. Hal tersebut dinyatakan oleh Yuliana et al. (2012) bahwa Bacillariophyceae memiliki penyebaran yang luas di perairan Teluk Jakarta.

M. engeli juga memanfaatkan perifiton kelas Bacillariophyceae sebagai kelompok makanan utamanya. Bacillariophyceae yang memiliki proporsi tinggi dibandingkan larva Nematoda dan detritus dapat diduga karena kelimpahan Bacillariophyceae yang melimpah di perairan, khususnya Teluk Pabean. Andriani et al. (2017) melaporkan bahwa Bacillariophyceae memiliki kelimpahan yang tinggi di Teluk Pabean. Teluk Pabean, yang termasuk perairan estuari dengan substrat dominan lumpur, diduga menjadi salah satu faktor penentu tingginya kelimpahan Bacillariophyceae atau Diatom dan Dinoflagellata (Nybakken 1997).

Tidak hanya perifiton kelas Bacillariophyceae yang dominan, detritus juga menjadi makanan yang memiliki proporsi tinggi. Pada ikan Mugil cephalus di estuari laguna tropis Tenggara, Nigeria (Soyinka \& Olukolajo 2008) dan Mugil cephalus di pesisir Timur Andhra Pradesh, India (Rao \& Babu 2013) juga ditemukan detritus yang dominan. Makanan yang terdiri atas kelompok perifiton dan detritus, tentunya berkaitan dengan morfologi organ pencernaan dan habitat ikan belanak di perairan estuari. Organ pencernaan beru- pa tapis insang yang panjang dan rapat, tembolok yang dikelilingi pilorik kaeka serta usus yang relatif panjang merupakan adaptasi terhadap makanan ikan belanak (Cardona 2016).

Pleurosigma menjadi jenis perifiton yang banyak dimanfaatkan oleh C. subviridis (Tabel 2). Empat spesies ikan belanak di pesisir laguna, Ghana juga banyak memanfaatkan Pleurosigma sebagai makanannya (Blay 1995). M. engeli juga memanfaatkan perifiton kelas Bacillariophyceae sebagai kelompok makanan utamanya, tetapi jenis makanan dominan yang dimanfaatkannya berbeda yaitu Nitzschia (Tabel 2). Nybakken (1997) menyatakan bahwa Nitzschia merupakan salah satu perifiton kelas Bacillariophyceae yang banyak ditemukan di perairan estuari.

Ikan belanak yang memanfaatkan perifiton dan detritus sebagai makanannya tidak hanya terjadi di Teluk Pabean. Perifiton dan detritus juga dimanfaatkan oleh Mugil cephalus di estuari laguna tropis Tenggara, Nigeria (Soyinka \& Olukolajo 2008), Mugil cephalus di pesisir Timur Andhra Pradesh, India (Rao \& Babu 2013), serta C. subviridis dan Valamugil buchanani di estuari Merbok, Kedah, Malaysia (Fatema et al. 2015a).

Pada setiap bulan pengamatan makanan C. subviridis dan $M$. engeli cenderung memiliki kesamaan, hanya saja proporsi serta komposisi makanan utama yang berbeda (Tabel 3, 4). Pleurosigma dan Nitzschia merupakan jenis makanan utama yang memiliki proporsi tinggi setiap bulan pengamatan. Coscinodiscus dan detritus juga memiliki proporsi yang relatif tinggi setiap bulan pengamatan. Proporsi Pleurosigma yang tinggi selama pengamatan juga terdapat pada empat spesies ikan belanak di pesisir laguna, Ghana (Blay 1995).

Perubahan proporsi makanan yang dikonsumsi oleh kedua spesies terjadi seiring dengan perubahan waktu. Proporsi makanan yang beru- 
bah pada setiap bulan pengamatan dapat disebabkan oleh ketersediaan makanan di perairan, di antaranya kelimpahan Bacillariophyceae (Andriani et al. 2017), penyebaran organisme makanan di perairan serta perubahan kondisi lingkungan (Simanjuntak \& Rahardjo 2001). Selain itu, Tampubolon \& Simanjuntak (2009) menyatakan bahwa ketersediaan makanan alami di suatu perairan juga berkaitan dengan musim.

Tidak hanya dominan setiap bulan pengamatan, perifiton dan detritus juga dominan pada setiap kelompok ukuran panjang baku (Tabel 5 dan 6). C. subviridis memiliki delapan jenis perifiton yang dominan pada setiap kelompok ukurannya. Berbeda dengan $M$. engeli, pada setiap kelompok ukurannya hanya empat jenis perifiton yang dominan. Pada kelompok ukuran sedang, variasi jenis makanan yang ditemukan lebih tinggi daripada kelompok ukuran panjang lainnya dan umumnya didominasi oleh kelas Bacillariophyceae.

Proporsi Bacillariophyceae dan detritus pada setiap kelompok ukuran panjang berfluktuasi tapi cenderung sama. Bacillariophyceae yang dominan dikonsumsi sebagai makanan ikan belanak berkaitan dengan kondisi kelimpahan Bacillariophyceae yang tinggi di perairan Teluk Pabean (Andriani et al. 2017). Perubahan jenis, ukuran, dan proporsi makanan yang dimanfaatkan oleh C. subviridis dan M. engeli pada setiap kelompok ukuran panjang tidak berbeda nyata. Hal ini serupa dengan perubahan makanan pada ikan tembang di perairan Teluk Kendari, Sulawesi Tenggara (Asriyana et al. 2004).

Proporsi detritus yang tinggi sebagai makanan ikan belanak dapat diduga dari produksi detritus di Teluk Pabean tinggi. Kondisi teluk yang masih dikelilingi oleh vegetasi mangrove memberikan potensi produksi detritus yang tinggi pada perairan tersebut (Zamroni \& Rohyani
2008). Proporsi detritus yang relatif tinggi pada bulan Desember juga karena adanya pengaruh musim dan curah hujan, sehingga detritus tersebut banyak termakan oleh ikan belanak.

Curah hujan yang tinggi pada musim penghujan mengakibatkan pergerakan arus di perairan semakin tinggi. Selain itu, pergerakan gelombang pasang dan penggenangan air laut lebih lama terhadap detritus, sehingga laju pengikisan atau penguraian detritus juga semakin tinggi (Sa'ban et al. 2013). Proporsi detritus yang tinggi juga berkaitan dengan proporsi plankton dan perifiton kelas Bacillariophyceae yang tinggi di Teluk Pabean. Hal ini serupa dengan penelitian di perairan mangrove Teluk Moramo (Sa'ban et al. 2013).

\section{Luas dan tumpang tindih relung makanan}

Variasi jenis makanan yang ditemukan pada kedua spesies relatif sama, kecuali beberapa jenis makanan yang ditemukan pada C. subviridis namun tidak ditemukan pada $M$. engeli. Hal tersebut ditunjukkan oleh nilai luas relung makanan C. subviridis yang lebih tinggi dibandingkan M. engeli (Tabel 7 dan 8). Selain itu, kelompok ukuran sedang ikan belanak memiliki nilai luas relung yang tinggi dibandingkan kelompok ukuran lainnya. Hal tersebut terlihat pada tingginya variasi jenis makanan kedua spesies ikan di kelompok ukuran tersebut (Tabel 5 dan 6). Nilai luas relung makanan akan tinggi ketika suatu organisme memanfaatkan makanan yang beragam dalam jumlah yang relatif sama (Krebs 1989).

Luas relung makanan yang tinggi pada kelompok ukuran sedang diduga karena pada ukuran tersebut ikan belanak membutuhkan lebih banyak energi untuk proses pematangan gonad. Rahman et al. (2015) menyatakan bahwa ikan C. subviridis jantan dan betina memiliki 
panjang kali pertama matang gonad pada ukuran 131 dan 145 mm. Wigati \& Syafei (2013) juga menyatakan bahwa $M$. engeli jantan dan betina memiliki panjang kali pertama matang gonad terkecil pada ukuran 135 dan $145 \mathrm{~mm}$.

Variasi makanan yang berupa larva organisme banyak ditemukan pada kelompok ukuran sedang. Larva organisme memberikan asupan energi berupa protein untuk proses perkembangan gonad. Habibi et al. (2013) menyatakan bahwa kandungan protein pada makanan ikan akan memengaruhi proses perkembangan gonad. Marzuqi et al. (2015) menegaskan bahwa protein merupakan salah satu nutrien dalam makanan ikan yang penting untuk perkembangan dan pematangan gonad.

C. subviridis dan $M$. engeli memiliki tumpang tindih relung makanan yang relatif rendah. Nilai tersebut mengindikasikan tidak adanya kesamaan pemanfaatan makanan pada kedua spesies. Hal ini ditunjukkan oleh variasi makanan dan nilai luas relung yang tinggi. Kondisi makanan juga melimpah di perairan Teluk Pabean selama pengamatan (Andriani et al. 2017). Kelimpahan makanan yang relatif tinggi tidak akan menimbulkan persaingan dalam memperoleh makanan (Ekpo et al. 2014).

Nilai tumpang tindih juga menggambarkan perubahan jenis makanan yang dimanfaatkan. Perubahan ini mengindikasikan adanya perbedaan jenis makanan yang dimanfaatkan. Perbedaan ini dapat disebabkan oleh ketersediaan makanan, ukuran makanan, frekuensi pengambilan makanan, tingkat kerapatan tapis insang, dan tingkat kelaparan ikan (Pradini et al. 2001).

\section{Simpulan}

Komposisi makanan ikan belanak yang ditemukan terbagi menjadi tiga kelompok besar, yaitu 21 jenis perifiton, 9 larva organisme, dan detritus. Perubahan komposisi setiap jenis makanan terjadi pada setiap kelompok ukuran panjang ikan selama pengamatan. C. subviridis dan M. engeli memiliki relung makanan yang luas dengan nilai luas relung masing-masing sebesar 5,995 dan 5,780. Pemanfaatan makanan yang sama relatif kecil terjadi pada $C$. subviridis dan M. engeli dengan nilai tumpang tindih 0,037.

\section{Persantunan}

Penulis mengucapkan terima kasih kepada tim penelitian Teluk Pabean II, staf Laboratorium Biologi Makro, Pak Kirwan, Pak Swara dan Bu Swara serta keluarga nelayan lainnya di Teluk Pabean yang telah membantu tim selama kegiatan penelitian di lapangan.

\section{Daftar pustaka}

Andriani A, Damar A, Rahardjo MF. 2017. Kelimpahan fitoplankton sebagai makanan ikan di Teluk Pabean, Jawa Barat. Jurnal Sumberdaya Akuatik Indopasifik, 1(2): 1122.

Asriyana, Sulistiono, Rahardjo MF. 2004. Kebiasaan makanan ikan tembang, Sardinella fimbriata Val. (Fam. Clupeidae) di perairan Teluk Kendari Sulawesi Tenggara. Jurnal Iktiologi Indonesia. 4(1): 43-50.

Blay JJR. 1995. Food and feeding habits of four species of juvenile mullet (Mugillidae) in a tidal lagoon in Ghana. Journal of Fish Biology. 46(1): 134-141.

Cardona L. 2016. Food and feeding of Mugilidae. In: Crosetti D, Blaber S (editor). Biology, Ecology and Culture of Grey Mullet (Mugilidae). CRC Press. New York p 165-190.

Davis CC. 1955. The Marine and Fresh-Water Plankton. Michigan State University Press. 562p.

Djumanto, Gustiana M, Setyobudi E. 2015. Dinamika populasi ikan belanak, Chelon subviridis (Valenciennes, 1836) di muara Sungai Opak - Yogyakarta. Jurnal Iktiologi Indonesia. 15(1): 13-24. 
Ekpo IE, Essien-Ibok MA, Nkwoji JN. 2014. Food and feeding habits and condition factor of fish species in Qua Iboe River estuary, Akwa Ibom State, southeastern Nigeria. International Journal of Fisheries and Aquatic Studies. 2(2): 38-46.

Fatema K, Omar MWM, Isa MM. 2015a. Variation of food items in the stomach contents of two Mullet, Chelon subviridis and $\mathrm{Va}$ lamugil buchanani, from Mebrok. Bangladesh Journal of Zoology. 43(2): 213-220.

Fatema K, Omar MWM, Isa MM. 2015b. Analysis of stomach contents in green back mullet Chelon subviridis from merbok estuary, Malaysia. Bangladesh Journal of Zoology. 43(1): 153-156.

Habibi, Sukendi, Aryani N. 2013. Kematangan gonad ikan sepat mutiara (Trichogaster leeri $\mathrm{Blkr}$ ) dengan pemberian pakan yang berbeda. Jurnal Akuakultur Rawa Indonesia. 1(2): 127-134.

Harrison IJ, Senou H. 1999. Order Mugiliformes. In: Carpenter KE \& Niem VH (editor). FAO Species Identification Guide for Fishery Purposes. The Living Marine Resources of the Western Central Pacific. Volume 4. Bony Fishes part 2 (Mugilidae to Carangidae). Rome (IT): FAO. p 20692108.

Isangedighi IA, Udo PJ, Ekpo IE. 2009. Diet composition of Mugil cephalus (Pisces: Mugilidae) in the cross river estuary, Niger Delta, Nigeria. Nigerian Journal of Agriculture, Food and Environment, 5(24): $10-15$.

Krebs CJ. 1989. Ecological Methodology. Harper Collins Publisher. Inc. New York 654 p.

Marzuqi M, Giri INA, Setiadharma T, Andama-ri R, Andriyanto W, Astuti NWW. 2015. Penggunaan pakan prematurasi untuk peningkatan perkembangan gonad pada calon induk ikan bandeng (Chanos chanos Forsskal). Jurnal Riset Akuakultur. 10(4): 519-530.

Natarajan AV, Jhingran AG. 1961. Index of preponderance: a method of grading the food elements in the stomach analysis of fishes. Indian Journal of Fisheries. 8(1): 54-59.

Nybakken JW. 1997. Marine Biology: An Ecological Approach 4th ed. Addison-Wesley Educational. 481 p.
Pradini S, Rahardjo MF, Kaswadji R. 2001. Kebiasaan makanan ikan lemuru (Sardinella lemuru) di perairan Muncar, Banyuwangi. Jurnal Iktiologi Indonesia. 1(1): 4145.

Rahman MAU, Mohanchander P, Lyla PS, Khan SA. 2015. Reproductive characteristics of greenback mullet, Liza subviridis (Valenciennes, 1936) from Parangipettai waters (Southeast Coast of India). International Journal of Pure and Applied Zoology. 3(3): 240-250.

Rachman A, Herawati T, Hamdani H. 2012. Kebiasaan makanan dan luas relung ikan di Cilalawi Waduk Jatiluhur Kabupaten Purwakarta Provinsi Jawa Barat. Jurnal Perikanan dan Kelautan. 3(2): 79-87.

Rao RK, Babu KR. 2013. Studies on food and feeding habits of Mugil cephalus (Linnaeus, 1758) East Coast Off Andhra Pradesh, India. Canadian Journal of Pure \& Applied Sciences. 7(3): 2499-2504.

Sa’ban, Ramli M, Nurgaya W. 2013. Produksi dan laju dekomposisi detritus mangrove dengan kelimpahan plankton di perairan mangrove Teluk Moramo. Jurnal Mina Laut Indonesia. 3(12): 132-146.

Sentosa AA, Satria H. 2011. Relung ekologi beberapa ikan target hasil tangkapan bubu di sekitar terumbu buatan perairan Teluk Saleh, Nusa Tenggara Barat. Jurnal Literatur Perikanan Indonesia. 17(3): 209-219.

Simanjuntak CPH, Rahardjo MF. 2001. Kebiasaan makanan ikan tetet (Johnius belangerii) di perairan mangrove pantai Mayangan, Jawa Barat. Jurnal Iktiologi Indonesia. 1(2): 11-17.

Soyinka, Olukolajo O. 2008. The feeding ecology of Mugil cephalus (Linnaeus) from a high brackish tropical lagoon in Southwest, Nigeria. African Journal on Biotechnology. 7(22): 4192-4198.

Sulistiono, Arwani M, Aziz KA. 2001. Pertumbuhan ikan belanak (Mugil dussumieri) di perairan Ujung Pangkah, Jawa Timur. Jurnal Iktiologi Indonesia. 1(2): 39-47.

Tampubolon PARP, Simanjuntak CPH. 2009. Kebiasaan makanan ikan motan Thynnichthys thynnoides, Bleeker, 1852 di rawa banjiran sungai Kampar Kiri, Riau. Jurnal Iktiologi Indonesia. 9(2): 195-201. 
Wahyuni T, Sulistiono, Affandi R. 2004. Kebiasaan makanan ikan buntal pisang (Tetraodon lunaris) di perairan Mayangan, Jawa Barat. Jurnal Iktiologi Indonesia. 4(1): 25 30 .

Wigati KN, Syafei LS. 2013. Biologi reproduksi ikan belanak (Moolgarda engeli, Bleeker 1858) di pantai Mayangan, Jawa Barat. Jurnal Iktiologi Indonesia. 13(2): 125132.

Wijeyaratne MJS, Costa HH. 1990. Food and feeding of two species of grey mullets Valamugil buchanani (Bleeker) and Liza vaigiensis quoy and gaimard inhabiting brackishwater environments in Srilanka. Indian Journal Fisheries. 37(3): 211-219.

Yamaji I. 1979. Ilustrations of the Marine Plankton of Japan. Japan (JP): Hoikusha Publishing Co. Ltd. 537 p.

Yuliana, Adiwilaga EM, Harris E, Pratiwi NTM. 2012. Hubungan antara kelimpahan fitoplankton dengan parameter fisik-kimiawi perairan di Teluk Jakarta. Jurnal Akuatika. 3(2): 169-179.

Zamroni Y, Rohyani IS. 2008. Produksi serasah hutan mangrove di perairan pantai Teluk Sepi, Lombok Barat. Jurnal Biodiversitas. 9(4): 284-287. 